\title{
Hedging Interest Rate Risk with Financial Futures: Some Basic Principles
}

\author{
Michael T. Belongia and G. J. Santoni
}

F

OR much of the postwar period, stable rates of inflation - accompanied by stable levels of interest rates - created a comforting economic environment for managers of depository institutions. Beginning in the mid-1970s, however, more variable interest rates, brought about in part by more variable inflation, caused a substantial change in the economic conditions facing depository institutions. Offering long-tem credit at fixed rates became riskier as larger and more frequent unexpected changes in interest rates introduced more variation into the market value of these assets."

This article describes how variation in interest rates affects the market value of depository institutions. The discussion then demonstrates how financial futures contracts might be used to hedge some of the interest rate risk of a portfolio composed of interest-sensitive deposit accounts and loans of unmatched maturities. Although some regulatory authorities have denied or strictly regulated the use of futures contracts by de-

Michael T. Belongia is an economist and G. J. Santoni is a senior economist at the Federal Reserve Bank of St. Louis. John G. Schulte provided research assistance.

For a general description of events that have introduced or increased interest rate risk, see Carrington and Hertzberg (1984) and Koch, et al. (1982). pository institutions in the belief that futures trading is risky and unduly speculative, we argue that the judicious use of futures can reduce the firm's exposure to interest rate fluctuations.?

\section{DURATION GAP AND INTEREST RATE RISK}

In the mid-1970s, when large fluctuations in interest rates began to occur, it became increasingly evident that depository institutions needed some measure of the relative risks associated with various portfolio holdings. One approach to the measurement of inter est rate risk is called Duration Gap analysis. "Duration" refers to the "average" life of some group of assets or liabilities. "Gap" refers to the difference between the durations of an institution's assets and its liabilities."

\footnotetext{
Legal restrictions and guidelines on the use of financial futures by different types of financial institutions are summarized in Lower (1982). A comparison of statutes on the use of futures by insurance companies is made in Gottlieb (1984).

${ }^{3}$ For more detaited discussions of duration analysis and its application to financial institution porttolios, see Kaufman (1984); Bierwag, Kaufman and Toevs (1983): Toevs (1983); Santoni (1984); Samuelson (1944); and Hicks (1939), pp. 184-88.
} 


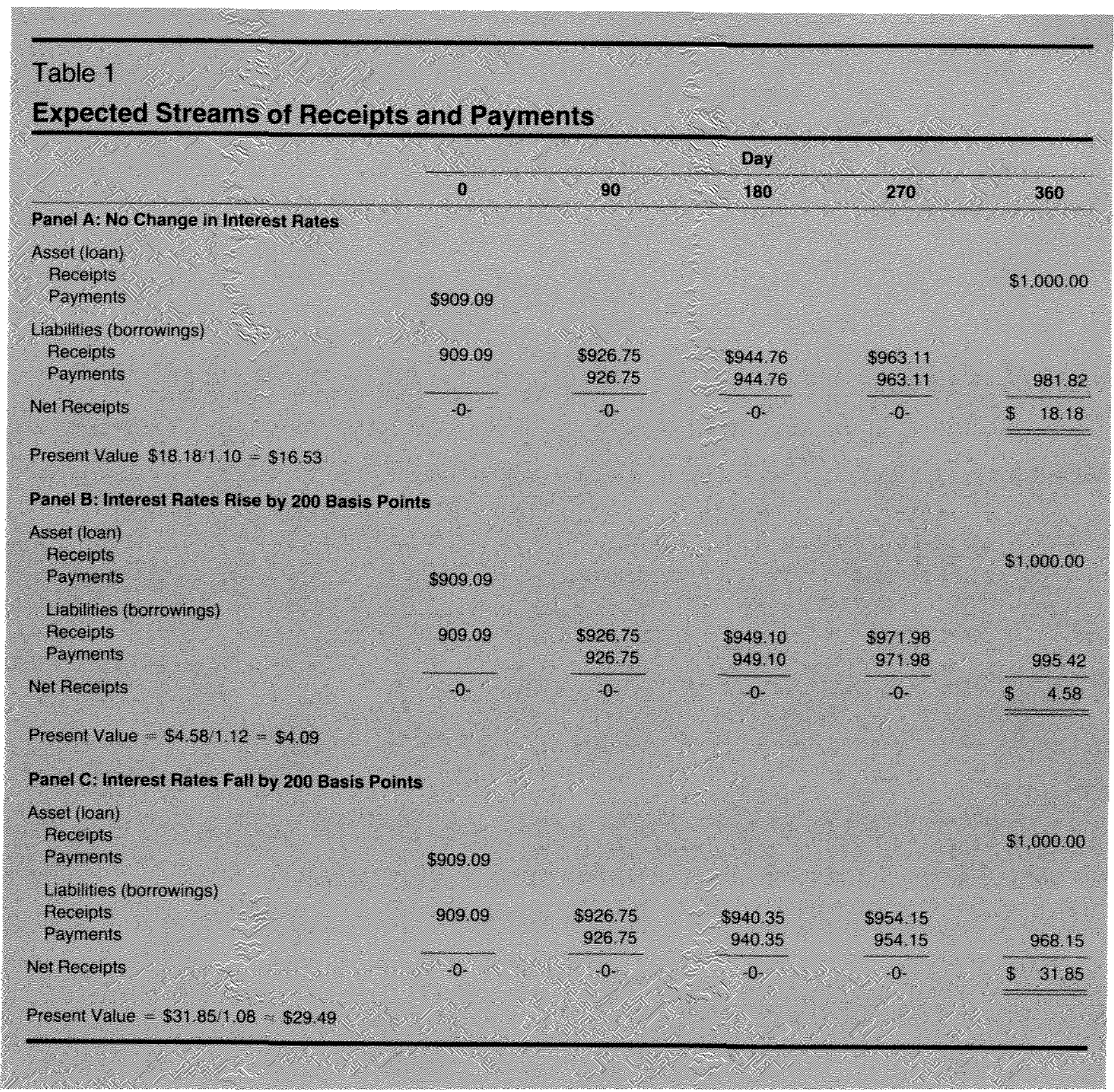

\section{An Example}

The risk introduced into a portfolio of assets and liabilities of different duration is illustrated in tables 1 and 2. In this example, for expositional simplicity, the firm's planned life is assumed to be only one year. It has extended a loan with a face value of $\$ 1,000$ to be repaid in a single payment at the end of the year at an interest rate of 10 percent. The present value of the loan, and, thus, the amount paid out by the firm to the botrower, is $\$ 909.09$. To finance this loan, the firm borrows $\$ 909.09$ for 90 days at 8 percent interest. The two percentage-point spread is the retum eamed by the firm for employing its specialized capital in intermediating between borrowers and lenders.

The amount that the firm will owe in three months time is $\left.\$ 926.751=\$ 909.09(1.08)^{25}\right)$, which it plans to pay by borrowing this amount for another 90 days. Because the firm's proceeds from the new loan and its payment of the old loan cancel, its net receipts at this time are zero. The firm anticipates being able to roll the loan over every 90 days at the same interest rate. Consequently, at the end of 180 days, the firm expects to owe $\$ 944.76\left(=\$ 926.75(1.08)^{23}\right)$, which it plans to pay with new borrowings. At the end of the year, the firm 


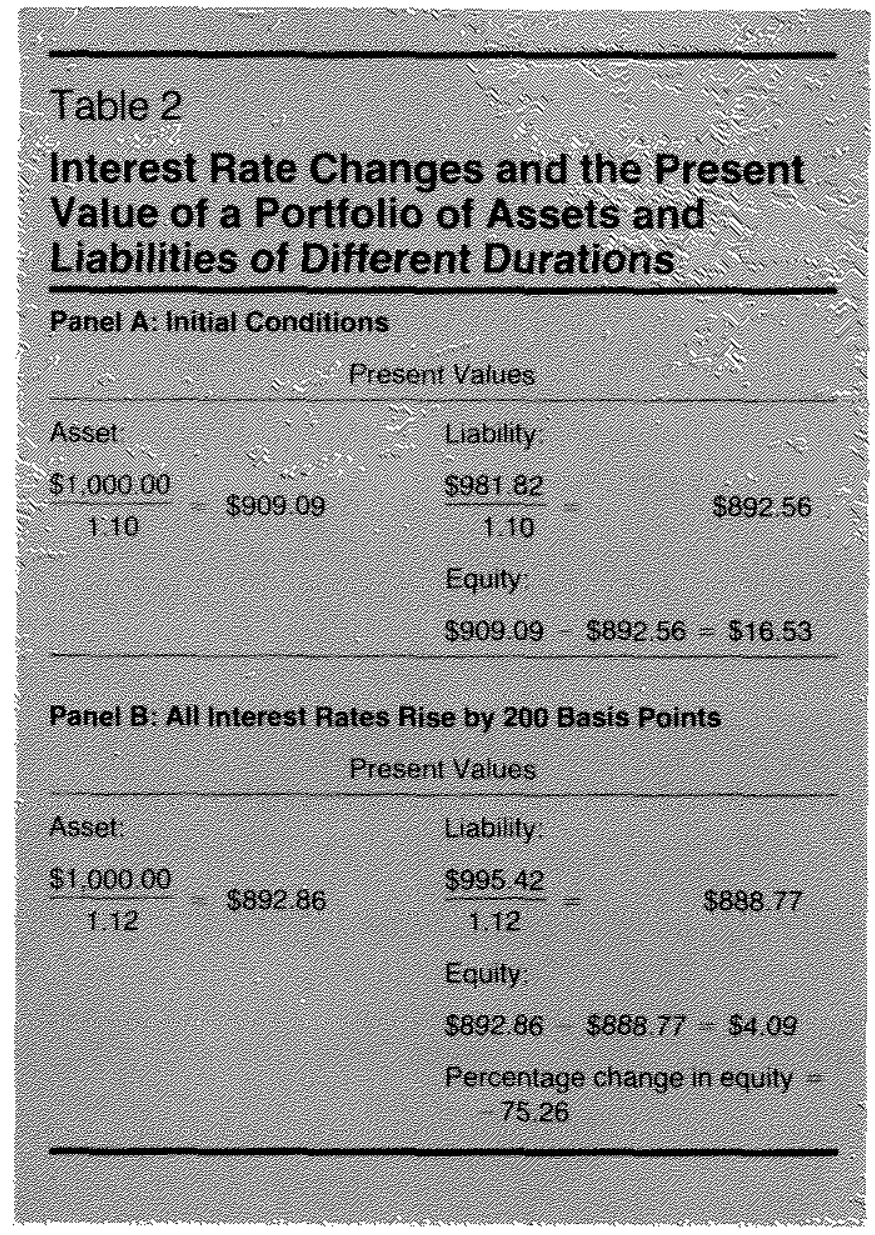

anticipates having to pay $\$ 981.821=\$ 909.09 \times 1.08$ ) This amount will be paid out of the $\$ 1,000$ proceeds from its matured asset. The firm's expected net receipt at year-end is $\$ 18.18$, as shown in panel $A$ of table 1 .

Panel A of table 2 is a balance sheet summary of the present value of this investment plan. The present value of the expected net receipt at year-end is $\$ 16.53$ and is equal to the difference between the present value of the asset, $\$ 909.09:=\$ 1,000 / 1.10)$, and the present value of the expected liability, $\$ 892.56$ $i=\$ 981.82 / 1.10$. Both future values are discounted at 10 percent, the firm's opportunity cost.

\section{The whots of Charging Ineresh hates on}

This package of assets and liabilities is subject to considerable interest rate risk because the 10 percent interest rate on the firm's loan is fixed for one year while its borrowings must be refunded every 90 days. In this example, the gap between the durations of the asset and liability is 270 days $(=360-90)^{4}$ As a practical matter, the asset's longer duration implies that a given change in interest rates will change the present value of the asset more than it will affect the present value of the liability. This difference, of course, will change the value of the firm's equity.

Panel $B$ of table 1 shows the effect of an unexpected 200 basis-point rise in interest rates. The increase raises the firm's anticipated refunding costs. As a result, the amount the firm expects to pay at year-end increases to $\$ 995.42$. Net receipts fall to $\$ 4.58$ and the present value of the investment plan falls to $\$ 4.09$.

Panel B of table 2 presents a balance sheet summary of the effect of the change on the present values of the asset, liability and owner equity. The increase in interest rates reduces the present values of both the asset and liability, but the asset value falls by relatively more because its life is fixed for one year, while the liability must be rolled over in 90 days at a higher interest rate. The increase in interest rates causes owner equity to fall by $\$ 12.44$, or about 75 percent. In contrast, had the interest rate dectined by 200 basis points, the net present value of the firm's equity would have risen to $\$ 29.49$ (see panel $\mathrm{C}$ of table 1 ), an increase of about 78 percent.

This extreme volatility in the firm's equity is due to the mismatch of the durations of the asset and liability that make up the firm's portfolio. Table 3 illustrates this point. The only difference between this and ear lier examples is that, in table 3 , the duration of the liability has been lengthened to match the duration of the asset. While a 200 basis-point increase in the interest rate still causes the present value of the portfolio to fall, the change, $-\$ 0.30$ or -1.8 percent, is much less than before. Clearly, matching the durations of the asset and liability exposes the value of the portfolio to much lower interest rate risk.

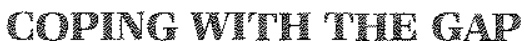

Depository institutions, particularly savings and loan associations, maintain portfolios of assets and liabilities that are similar to the one shown in the initial example. ${ }^{\bar{T}}$ That is, the duration of their assets

The durations of single-payment financial instruments are equal to the maturities of the instruments. In other cases, calculation of duration is not as straightorward. See lootnote 3 .

SSavings and loan associations are required to maintain a significant share of their portfolios in long-term home mortgages in order to obtain federal insurance of deposits. See Federal Fome Loan Bank Act of 1932 , sec. $4(a)$. 


\section{Table 3}

\section{Interest Rate Changes and the Present Value of a Portrolio of Assets and Liabilities of the Same Duration}

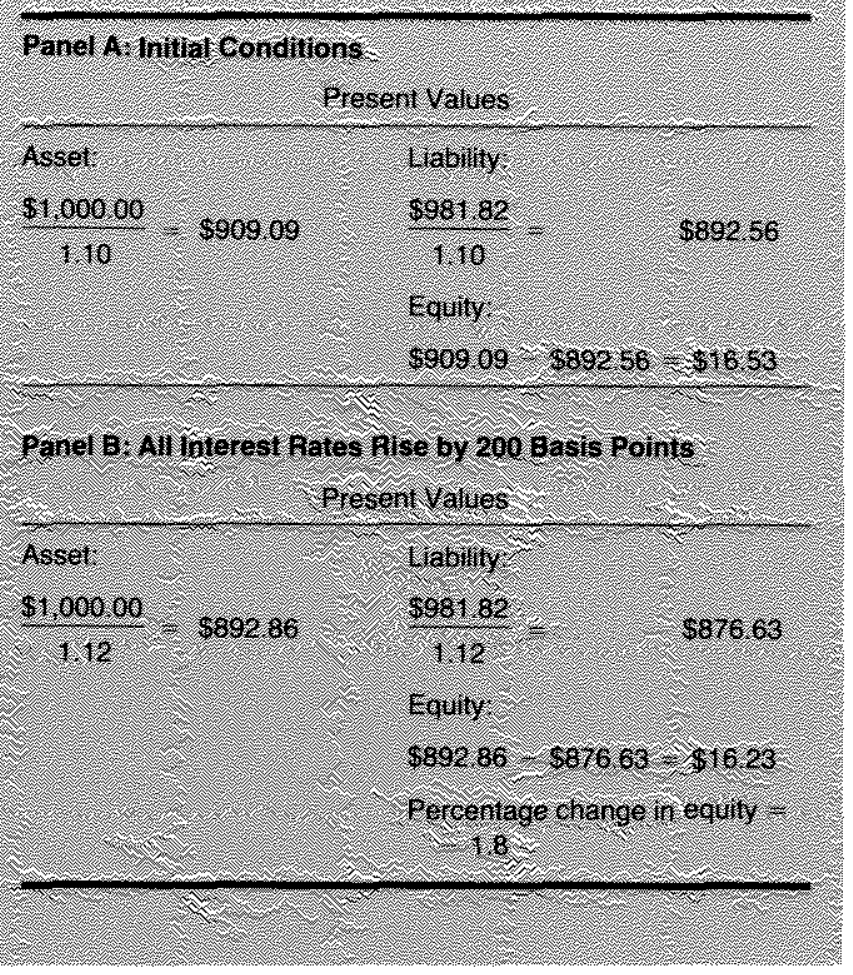

typically is longer than the duration of their liabilities. As a result, the market values of these institutions have been particularly sensitive to interest rate fluctuations. This, along with the recent experience of highly variable interest rates, has led these institutions to seek out methods to reduce their exposure to interest rate risk. Among other things, these firms have made greater use of floating rate loans and interest rate swap agreements. Recent regulatory changes have allowed them to allocate more of their loan portfolios to shortterm consumer loans. In addition, a number of institutions are using financial futures to reduce their exposure to interest rate risk. ${ }^{5}$

\footnotetext{
6See Booth, Smith and Stolz (1984). While a number of financial firms are employing the futures market, it seems that accounting requirements have discouraged the use of futures to hedge interest rate risk. Until recently, regulators and accountants feared that losses from futures transactions could be hidden in financial reports. Therefore, they would not permit a hedge to count as one transaction with spot gains or losses offsetting futures markets losses or gains. Instead, they required futures losses to be marked to the market while spot gains could be deferred. This asymmetric treatment of gains and losses on the two sides of a hedge distorted earnings estimates and, therefore, discouraged the use of futures.
}

\section{Futares Markets and Tisk}

It may seem odd that the futures market, which is generally thought of as being very risky, can be used to reduce risk. Futures trading is risky for people who bet on the future price movements of particular commodities or financial instruments by taking long or short positions in futures contracts. Such speculative bets on future price movements, however, are not unique to futures market trading. The nature of most types of businesses requires a speculative bet about the future course of a particular price.

Growing crops, for example, gives farmers long positions in physical commodities during the growing season. These long positions expose the farmer to the risk of price declines - declines that can reduce the profits from efficient farming the activity that the farmer specializes in/. Judicious use of the futures market allows the farmer to offset his long position in the commodity by selling futures contracts. Since the sale reduces his net holdings of the commodity, the farmer's exposure to the risk of future price declines is reduced. Similarly, futures trading presents depository institutions with the opportunity to reduce their exposure to the risk of interest rate changes.

\section{Whentes Contracts}

A futures contract is an agreement between a seller and a buyer to trade some well-defined item (wheat, corn, Treasury bills) at some specified future date at a price agreed upon now but paid in the future at the time of delivery. The futures price is a prediction about what the price of the item will be at the time of delivery.

In the case of commodities, the price of the good today (the spot price), on average, will be equal to the futures price minus the cost of storage, insurance and foregone interest associated with holding the good over the interval of the contract. A similar relationship exists between the spot and futures prices of financial instruments. However, since the storage and insurance cost of holding these instruments is very low, the spread between the spot and futures prices is largely determined by the interest cost.

\footnotetext{
See Morris (1984) for more detail on changes in accounting standards. Asay, et al. (1981) provide examples of how former accounting standards discouraged the use of futures by banks and thrift institutions.
} 


\section{The Relationship Between Spot and Futures Markets for Treasury Bills: An Illustration}

In January 1976 , the International Monefary Market (IMM), now part of the Chicago Mercantile Exchange (CME), began trading futures contracts in 13-week Treasury bills. The basic contract is for $\$ 1$ million with contracts maturing once each quarter in the third week of March, June, September and December. Since there are eight contracts outstanding, the most distant delivery date varies between 21 and 24 months into the future.

Panel A of table 4 presents quotations for Treasury bill futures for the trading day of August 7,1984 . Panel $B$ of table 4 lists spot quotations for Treasury bills for the same trading day.

Panel A of table 4 is interpreted as follows: September Treasury bill futures were trading at a discount of 10.49 percent on August 7,1984 . Any person trading this contract obtained the right to buy (sell) a Treasury bill the third week in september with a remaining maturity of 13 weeks at a discount rate of 10.49 percent. A similar statement holds for the other contracts listed in parel $A$.

Panel B lists spot market quotations. For example, Treasury bills due to mature August 9, 1984, traded at a discount of 9.91 percent (bid) to 9.79 percent lask), while those maturing September 20, 1984, traded at a discount of 9.95 (bid) to 9.91 (ask), etc.

We noted earlier that the spot and futures markets must be closely related, and the data in panels $A$ and $B$ can be used to illustrate this point. For example, on August 7,1984 , an investor could purchase a Treasury bill due to mature December 20,1984 li.e., 134 days later). If he purchases the bill on the spot market, he obtains the asked discount of 10.39 percent. At this discount rate, the price he pays for the bill is $\$ 96.41$ per $\$ 100$ of face value.

'Futures contracis in other types of financial instruments, such as GNMA passthrough certificate contracts, 90-day CDs, Treasury bonds and Treasury notes, also are avallable at the Chicago Board of Trade.

The information in table 3 is taken from pages 38 and 39 of the August 8,1984 . Wall Street Journal. The actual tables in the Walf Street Journaf contain more intomation than is presented here. For our purposes, however, the additional information is extraneous.

$9996.41=\$ 100 /(1.1039)^{37}$. The discount factor is raised to the power of $134 / 360=37$. This calculation is stightly different from the discount calculation used in determining actual trading prices, but

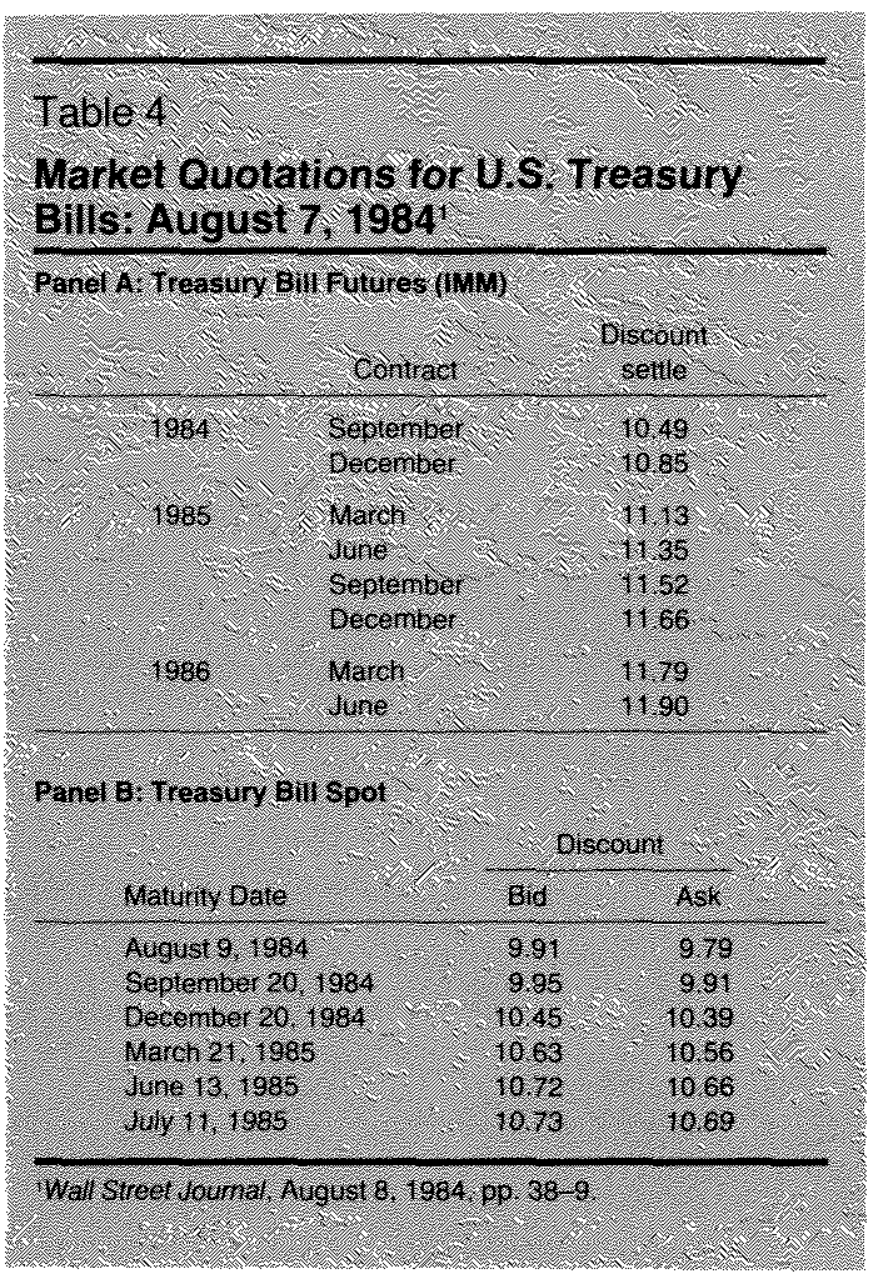

Alternatively, the investor could purchase a futures contract that gives him the right to buy a Treasury bill in September that will mature the third week in December. This alternative gives him a discount rate of 10.49 percent. Buying the Treasury bill in September at this discount would require a payment of $\$ 97.54 .{ }^{n}$ This payment will be made 43 days into the future, roughly, September 20, and the present value of the payment on August 7 is $\$ 96.44$. " Notice that this is very near the amount that the investor would pay $(\$ 96,41)$ if he were to purchase a Treasury bill on the spot market that matured during the third week of December.

Of course, other alternatives are open to the investor as well. He could, for example, buy a Treasury bill that matured the third week in March on the spot market.

numerical differences between the two formulas are small. See Stigum (1981) for the market's discount formula.

$10 \$ 97.54=\$ 100 /(1.1049)^{25}$.

$1 \$ 96.44=\$ 97.54 /(1.0991)^{12}$. The interest rate used in the calculation ss the rate on August 7 for a security maturing on September 20 ( 43 days in the future) 
The present cost of doing this should be near the present cost of buying a futures contract that allows him to purchase a Treasury bill in December maturing the third week in March. Table 5 uses the data in table 4 to compare the present costs of this and other altematives. In each case, the present costs of employing the spot vs. the futures market are very close. ${ }^{\mathrm{sz}}$ Because a close relationship between these markets exists, the Treasury bill futures market can be used effectively to hedge interest rate risk. ${ }^{13}$

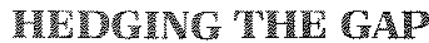

\section{The Streams of Receipls and Paynents}

The example in table 1 can be used to illustrate how futures contracts can be applied to hedge the interest rate risk caused by the mismatch in the lives (durations) of the firm's assets and liabilities. Considerable confusion appears to exist as to what the firm's hedg" ing objective should be and how hedges should be constructed. One possible hedging strategy is to protect the equity of the firm (in the present value sense) from interest rate fluctuations. Another often-cited strategy is to minimize discrepancies between cash flows over time. It seems clear, however, that firm owners will choose a hedge that protects their net wealth (present value of the firm's equity). This focus on net wealth is crucial because, as the examples show, reducing cash flow mismatches to zero does not minimize the exposure of the firm's equity to interest rate changes.

\section{Hedging Ner Wealn: An Example}

Suppose it is September 15, 1984, and the firm initiates the transactions summarized earlier in panel A of table 1. In addition, to hedge each of its three refunding requirements, the firm sells December, March and June futures contracts at 10 percent discounts. ${ }^{14}$ The price of each contract is $\$ 1,000 /(1,10)^{25}=$

\footnotetext{
"Small differences are due to the existence of transaction costs. If the differences were large, profitable arbitrage opportunities would exist. These, of course, would vanish quickly as traders took advantage of the situation.

3 There is, of course, the problem that the spot instrument being hedged may not be identical to the futures market instrument. If so, the price of one may diverge from the other because of a change in a factor that affects the price of one but not the other. This is called "basis risk" and is ignored in the following examples.

iA flat yieid curve is assumed for ease of exposition. The examples become more complicated if the yield curve slopes up or down and or the spread between borrowing and lending rates changes.
}

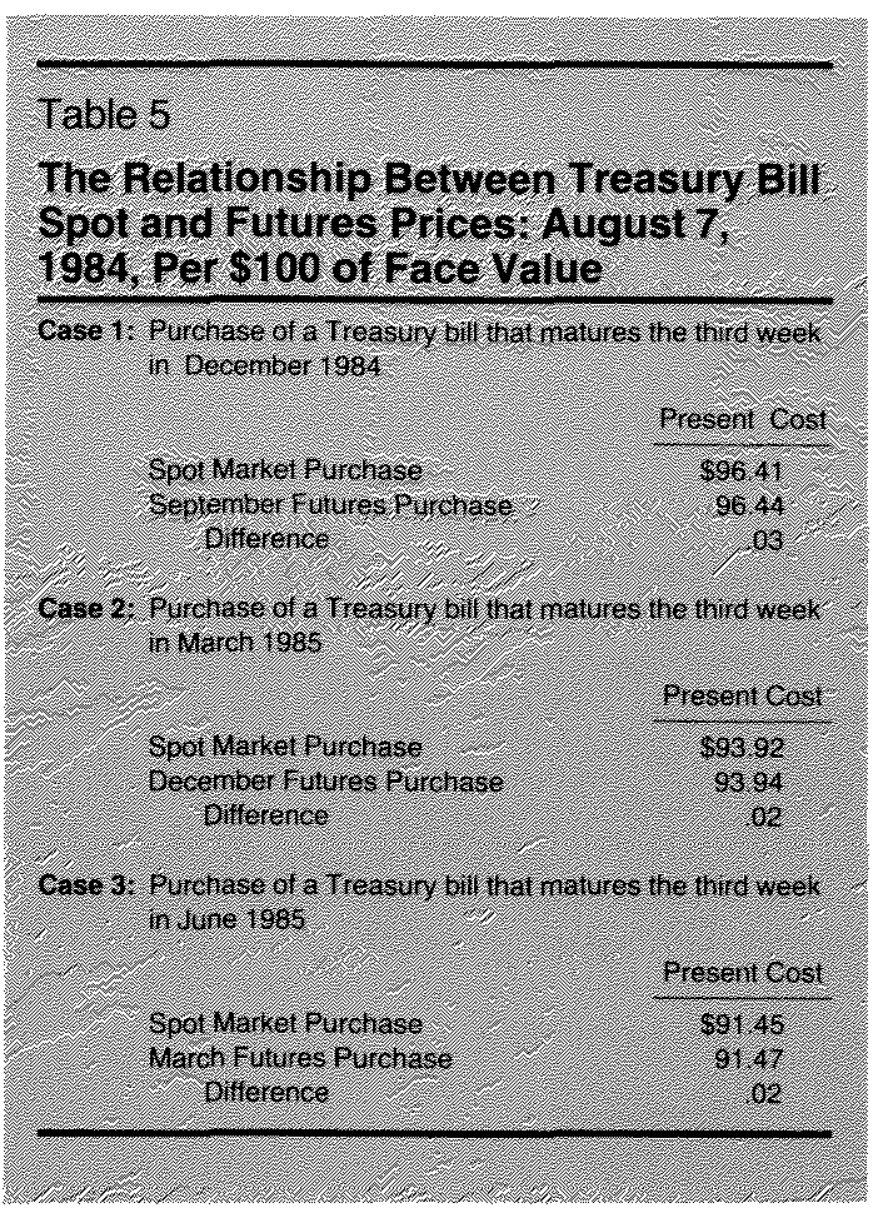

$\$ 976.45$. These contracts obligate the firm to deliver a 13-week Treasury bill with a face value of $\$ 1,000$ during the third week of December, March and June in exchange for $\$ 976.45$.

Panel A of table 6 presents the firm's expected streams of receipts and payments given the structure of interest rates on September 15. It is identical to panel A of table 1 except that the streams of receipts and payments generated by the futures contract are included. The futures contract generates a certain stream of receipts equal to $\$ 976.45$ in December, March and June in exchange for delivery of the 90-day Treasury bills. The firm must acquire these bills in order to make delivery and, on September 15, the expected cost of acquiring each of the Treasury bills is $\$ 976.45$. If interest rates remain unchanged, expected and actual costs will be the same so that the actual receipts and payments generated by the futures contract net out in each period. The net flow of receipts is $z$ zero until year-end when the firm receives $\$ 18.18$. The present value of this amount is $\$ 16.53$.

In panel $\mathrm{B}$, interest rates are assumed to rise unexpectedly by 200 basis points immediately following 


\section{Table 6}

\section{Expected Streams of Receipts and Payments}

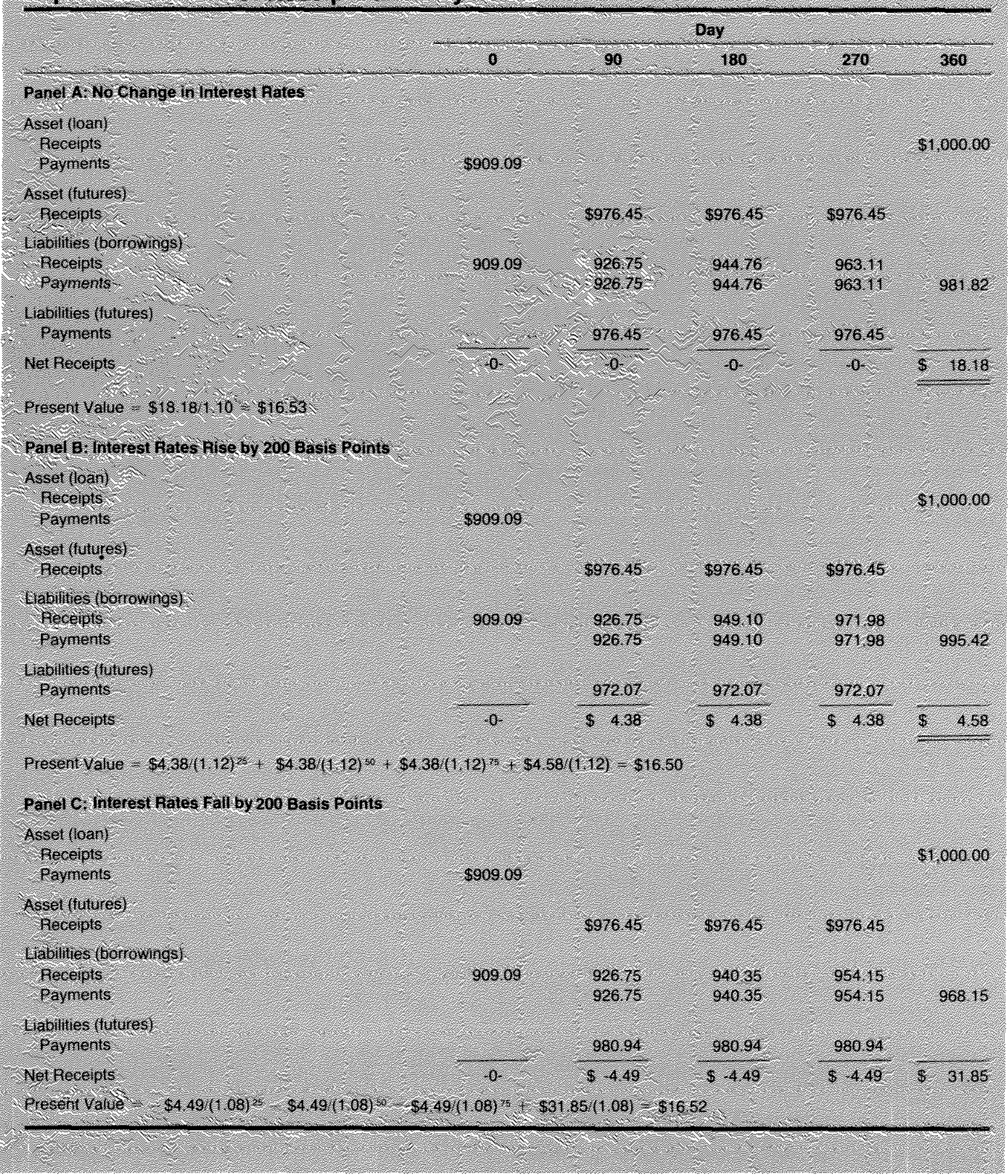


the firm's September 15 transactions. As in panel $B$ of table 1 , the increase in interest rates raises the firm's refunding cost and reduces the net year-end receipt to \$4.58. In addition, however, the increase in interest rates reduces the expected cost of acquiring the Treasury bill to $\$ 972.07$. Since the firm will receive $\$ 976.45$ upon delivery of the Treasury bills, the futures con+ tract will generate a net flow of receipts equal to $\$ 4.38$ in December, March and June. The present value of this flow added to the present value of the net receipt at year-end $\$ \$ 4.58)$ is $\$ 16.50$, which is nearly identical to the present value for the case in which interest rates remained unchanged the small difference is due to rounding errors).

Panel $C$ illustrates the outcome for a 200 basis-point decline in interest rates. In this case, the futures contract generates negative net receipts for the firm in December, March and June. The present value of this negative flow added to the present value of the higher positive net receipt at year-end sum to $\$ 16.52$. As the examples show, this hedge protects the net wealth of the firm regardless of the direction of the change in interest rates.

While this hedge protects net wealth from changes in interest rates, it does so by allowing net cash receipts to vary, Net cash receipts, both in amourt and timing, are considerably different in panels $A, B$ and $C$. In panel $A$, net receipts are $\$ 18.18$ at year-end while in panel $B$ net receipts are spread out over the year and total only $\$ 17.72$. In panel $C$, the firm has negative net receipts during the year and a large positive net receipt at year-end for a total of $\$ 18.38$. Howeves, the present value of the firm is the same in all three cases.

\section{The Balance Sheet}

Panel $A$ of table 7 presents the firm's balance sheet position in terms of present values. The futures contracts are entered as both assets and liabilities, leaving equity the same as that shown in panel $A$ of table $2^{13}$ The futures asset is the present value of the future receipt of a fixed amount. The futures liability, on the other hand, is the present value of the expected cost of covering the futures contract given the structure of interest rates on September 15 . Panels $B$ and $C$ illus-

\footnotetext{
15Strictly speaking, futures contracts entered into by member banks of the Federal Reserve System are treated as balance sheet memofanda items. These are reported on Schedule L, Commitments and Contingencies, of the Call Report. Hence, for accounting purposes, iutures contracts do not affect the assets and liabilities of the firm until the contracts are exercised.
}

trate the effect on the present values of the firm's assets, liabilities and equity if, immediately following the above transactions, interest rates rise unexpectedly (panel B) or fall unexpectedly (panel C) by 200 basis points.

An unexpected increase in interest rates causes the present value of the loan to fall relative to the present" value of the liability. By itself, this would cause a reduction in the firm's equity. At the same time, however, the increase in interest rates generates a positive expected net cash flow from the futures contracts, which, of course, has a positive net present value. Other things the same, this causes equity to rise. The net effect of both changes is that equity remains unchanged. The reverse occurs if interest rates decline by 200 basis points.

This hedge has eliminated the firm's exposure to interest rate risk. In contmast, recall that a 200 basispoint change in the interest rate causes the equity of the unhedged firm in table 2 to change by about 75 percent.

\section{Hedging as a "Profit Center"}

The purpose of hedging is to reduce the variance of a firm owner's wealth. In a textbook example of a perfect hedge, the gain or loss from a short position in the futures market will offset exactly the compensating loss or gain on the spot assets and liabilities held by the firm. A hedge is constructed because - in the presence of an uncertain future - wealth is greater if the institution foregoes a profit stream that is higher on average (if it goes unhedged in exchange for a profit stream that is lower on average by the cost of the hedging operations! but more certain.

Some portfolio managers, however, lose sight of this fact and assume speculative positions in the futures market with the objective of eaming profits from the position if interest rates change in their favor. While speculative positions in futures (or spot instruments) can increase earnings, they can have the opposite effect as well.

One potentially significant danger in the use of fitures contracts to hedge interest rate risk is that the firm may misunderstand the nature of the hedging function. Trading futures for hedging is not intended to generate profits from the trading itself. Rather, its purpose is to establish futures positions so that the owner's wealth is held constant; this will occur if the increase (decrease) in the value of the firm's spot holdings of assets and liabilities is offset exactly by the loss gain in the futures maket. 
Table 7

\section{Interest Rate Changes and the Present Value of a Hedged Firm}

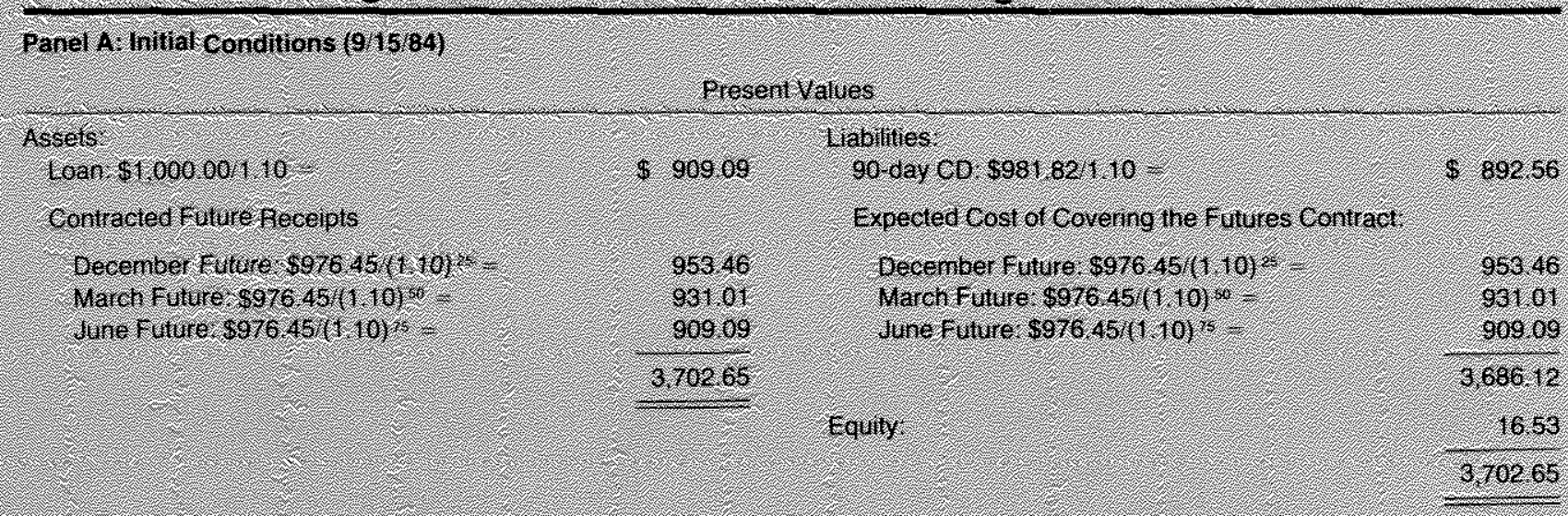

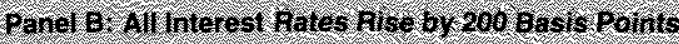

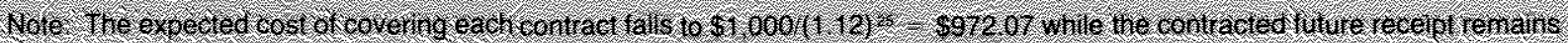
vinthanged

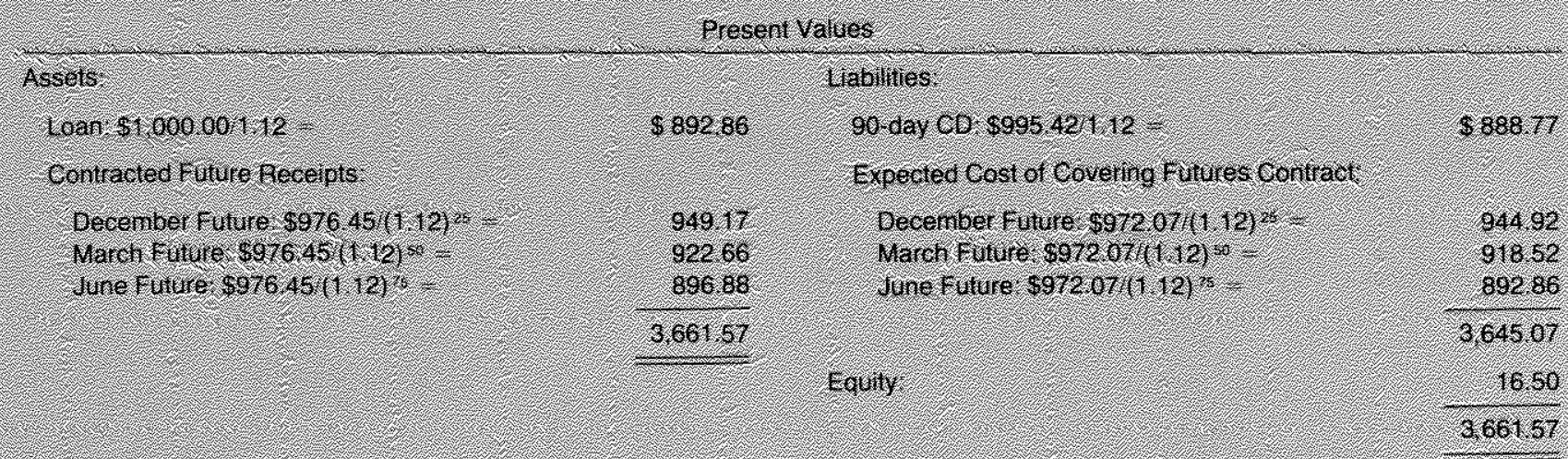

\section{Pandel Allinterest Rates rall by 200 basis roints}

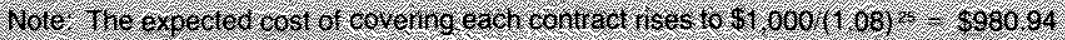

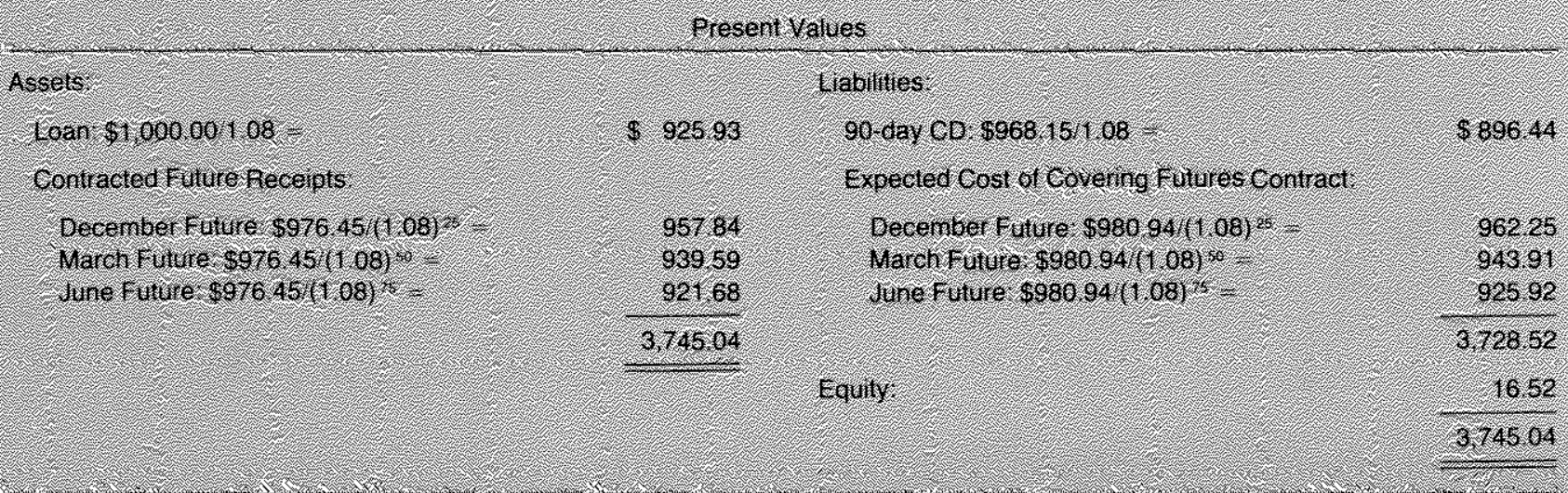




\section{Real World Complications in Hedghe}

The eximples in tables 6 and 7 simplith lost

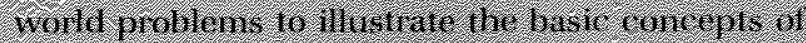

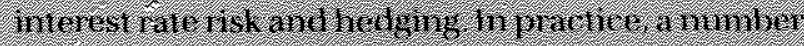
or teonplicating factors will nake the tonsimiton or a hedge consideribly more dificult.

The inst dificulf Io note is liat the callutation

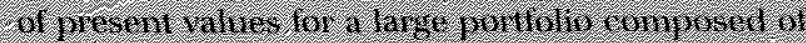

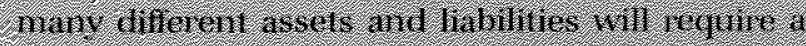
sicat deal of inlomation. Moreoter tesuirires will le neoded to estmate inerest das fieities lor dhir. tronst. And anhike our examples whith are based on single-payment loans and deposits of l nomb

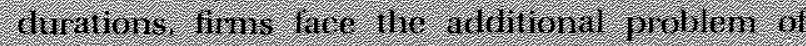
loans hat are sublect io einly vaument ind to

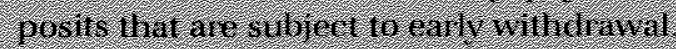

Dven with a gud esimale of its exposime it interest rate risk fims will face prached protulens in implementing a hedge I vically liquidivg is very

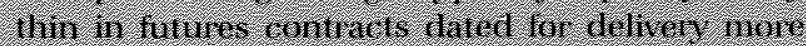

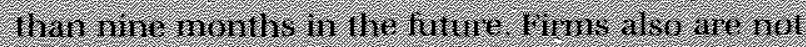
likely u find tutures contmets for the exact tomir amount hes wish to hedge or for the sperifie spot

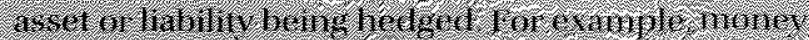

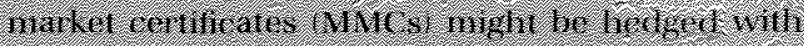

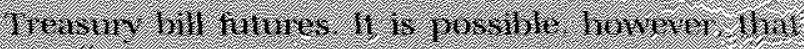

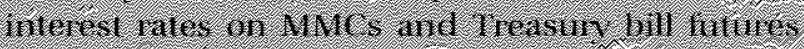

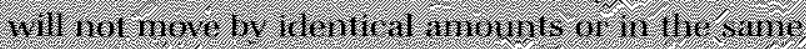

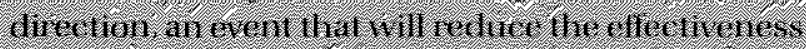

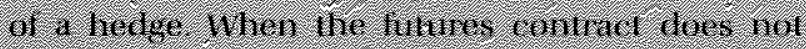
correspond txictle to the spot rommadity of in

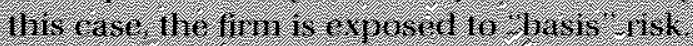

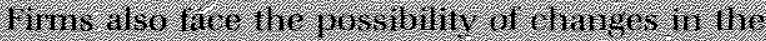

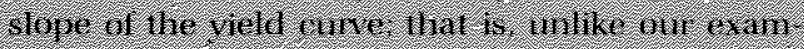

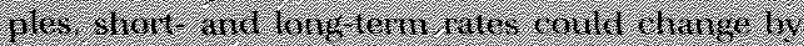

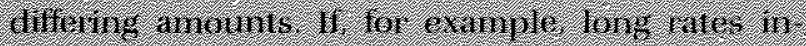

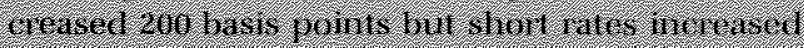

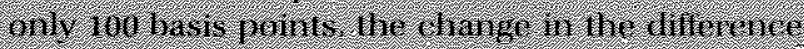
hemeen the prosent valures of spat assets and sport habilines wontd not he completely ofrst hn a

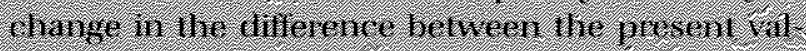
ines af the funires asset and halinty true hedges. linveres are implemented undur the esper fation

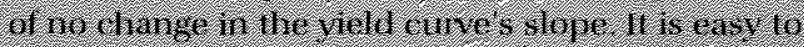

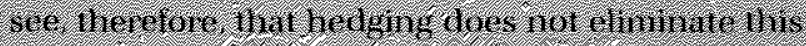
spunterot wisk

\section{SUMMARY}

Higher and more variable interest rates have increased the risk faced by financial institutions associated with attracting deposit funds and extending credit. This article presented some simple examples of techniques that can isolate and quantify sources of a financial institution's exposure to interest rate risk. The discussion also described how financial futures can be used to reduce this risk. A simple hedging example indicated that relatively conservative use of futures markets can have a potentially large impact on reducing risk exposure. The use of futures trading is a threat to the long-run performance of a financial firm only if applied in a manner inconsistent with hedging.

\section{PRPERENCES}

Asay, Michael R., Gisela A. Gonzalez, and Benjamin Wolkowitz. "Financial Futures, Bank Portiolio Risk, and Account" ing," Journal of Futures Markets (Winter 1981), pp. 607-18.

Bienwag, G. O., George G. Kauman and Alden Toevs. "Bond Portfolio Immunization and Stochastic Process Risk," Joumal of Bank Research (Winter 1983), pp. 282-91.
Booth, James R., Richard L. Smith, and Richard W. Stolz. "Use of Interest Rate Futures by Financial institutions," Journal of Bank Research (Spring 1984), pp. 15-20.

Carrington, Tim, and Danieł Hertzberg. "Financial institutions Are Showing the Strain of a Decade of Turmoil," Wall Street Journal (September 5,1984 ).

Federal Home Loan Bank Act of 1932. Public No. 304, 72 Cong., HR 12280

Gay, G. D., and A. W. Kolb. "The Management of Interest Pate Risk," Joumal of Portolio Management (Winter 1983), pp. 6570.

Gottlieb, Paul M. "New York and Comnecticut Permit insurers to Use Futures and Options: A Comparison," Chicago Mercantile Exchange Market Perspectives (May/June 1984), pp. $1-6$.

Hicks. J. R. Value and Capital (Oxford: Clarendon Press, 1939).

Kautman, George $\mathrm{G}$. "Measuring and Managing Interest Rate Risk: A Primer," Federal Reserve Bank of Chicago Economic Perspectives (January-February 1984), pp. 16-29

Koch, Donald L., Delores W. Steinhauser and Pamela Whigham. "Financial Futures as a Risk Management Tool for Banks and S\&Ls," Federal Reserve Bank of Atlanta Economic Review (September 1982), pp. 4-14.

Kolb, R. W. Interest Rate Futures: A Comprehensive introduction (Robert F. Dame, Inc., 1982).

Kolb, Robert W., Stephen G. Timme and Gerald D. Gay. "Macro Versus Micro Futures Hedges at Commercial Banks," Joumal of Futures Markets (Spring 1984), pp. 47-54. 
Lower, Robert $C$. Futures Trading and Financial institutions: The Regulatory Environment (Chicago Mercantile Exchange, $1982)$.

Morris, John, "FASB Issues Rules for Futures Accounting," American Banker (August 24, 1984).

Olson, Ronald $\mathrm{L}$. and Donald G. Simonson. "Gap Management and Market Rate Sensitivity in Banks." Joumal of Bank Re. search (Spring 1982), pp. 53-58.

Samuelson, P. A. "The Effect of interest Rate increases on the Banking System," American Economic Review (March 1944). pp. $16-27$.

Santoni, G. J. "Interest Rate Risk and the Stock Prices of Financial institutions," this Review (August/September 1984).
Simonson, Donald G. and George H. Hempel. "Improving Gap Management for Controlling Interest Rate Risk," Journal of Bank Research (Summer 1982), pp. \$09-15.

Stigum, Marcia. Money Market Calculations: Yields, Break-Evens and Arbitrage (Dow Jones-Irwin, 1981).

Toevs, Alden. "Gap Management: Managing Interest Rate Risk in Banks and Thrifts," Federal Feserve Bank of San Francisco Economic Review (Spring 1983), pp. 20-35.

Wardrep, Bruce N. and James F. Buch. "The Efficacy of Hedging with Financial Futures: A Historical Perspective," Journal of Fufures Markets (Fali 1982), pp. 243-54.



